\title{
Effects of golf course management on subsurface soil properties in lowa
}

\author{
Matthew T. Streeter and Keith E. Schilling \\ Iowa Geological Survey, 300 Trowbridge Hall, University of Iowa, Iowa City, IA 52242, USA \\ Correspondence: Matthew T. Streeter (matthew-streeter@uiowa.edu)
}

Received: 19 October 2017 - Discussion started: 2 January 2018

Revised: 21 March 2018 - Accepted: 14 April 2018 - Published: 3 May 2018

\begin{abstract}
Currently, in the USA and especially in the Midwest region, urban expansion is developing turfgrass landscapes surrounding commercial sites, homes, and recreational areas on soils that have been agriculturally managed for decades. Often, golf courses are at the forefront of conversations concerning anthropogenic environmental impacts as they account for some of the most intensively managed soils in the world. Iowa golf courses provide an ideal location to evaluate whether golf course management is affecting the quality of soils at depth. Our study evaluated how soil properties relating to soil health and resiliency varied with depth at golf courses across Iowa and interpreted relationships of these properties to current golf course management, previous land use, and inherent soil properties. Systematic variation in soil properties including sand content, $\mathrm{NO}_{3}$, and soil organic matter (SOM) were observed with depth at six Iowa golf courses among three landform regions. Variability in sand content was identified between the 20 and $50 \mathrm{~cm}$ depth classes at all courses, where sand content decreased by as much as $37 \%$. Highest concentrations of SOM and $\mathrm{NO}_{3}$ were found in the shallowest soils, whereas total $\mathrm{C}$ and $\mathrm{P}$ variability was not related to golf course management. Sand content and $\mathrm{NO}_{3}$ were found to be directly related to golf course management, particularly at shallow depths. The effects of golf course management dissipated with depth and deeper soil variations were primarily due to natural geologic conditions. The two abovementioned soil properties were very noticeably altered by golf course management and may directly impact crop productivity, soil health, and water quality, and while $\mathrm{NO}_{3}$ may be altered relatively quickly in soil through natural processes, particle size of the soil may not be altered without extensive mitigation. Iowa golf courses continue to be developed in areas of land use change from historically native prairies and more recently agriculture to urban landscapes. As soils are continually altered by human impacts, it is imperative that we monitor the changes, both physical and chemical, in order to establish management practices that maintain environmental sustainability and productivity.
\end{abstract}

\section{Introduction}

Critical evaluation of resilience and health of soil resources has been fueled by a recent urgency to understand anthropogenic impacts on environmental resources relating to local, regional, and international environmental sustainability and quality (Doran and Zeiss, 2000; Glanz, 1995). Urban expansion is a primary cause for these recent concerns. In the Midwest USA, especially in Iowa, urban expansion is altering decade-long agriculturally managed landscapes by developing turfgrass that surrounds commercial sites, homes, and recreational areas (Qian and Follett, 2002). In many Iowa communities, golf courses play a key role in conversations concerning anthropogenic environmental impacts since they account for some of the most intensively managed soils in the world (Balogh and Walker, 1992).

Limited information is available documenting changes in soils due to golf course management, especially at depth, since most studies focus on the rooting depth of turfgrass and near the surface where soils are engineered to ideal texture classes (Bauters et al., 2000). Qian and Follett (2002) conducted a study on the effects of land use change to turfgrass on soil organic matter (SOM) and found that previous 
land use imparted a strong baseline control. However, while this study analyzed data from nearly 700 data sets, the results were limited to the top $15 \mathrm{~cm}$ of soil. In contrast, an effect on deep soil quality from land use management has been observed in agricultural systems. Tomer and Burkart (2003) observed a significant increase in soil nutrient concentrations at a depth of $17 \mathrm{~m}$ below ground surface that was associated with historical fertilizer applications that had occurred 20 years prior. Furthermore, they estimated $\mathrm{NO}_{3}-\mathrm{N}$ percolation rates in loess soils to be approximately $0.67 \mathrm{~m} \mathrm{yr}^{-1}$. With the apparent decades-long translocation of soil nutrients after agricultural soil management, it is of interest to determine whether golf course management is similarly affecting the resiliency and long-term sustainability of soil resources.

There are over 400 golf courses in Iowa and many of these have been in operation for decades. With some of the most productive agricultural soils in the world, Iowa golf courses provide an ideal location to evaluate whether golf course management is affecting the quality of soils at depth. Specifically, our study objectives were to (1) evaluate how soil physical and chemical properties relating to soil health and resiliency varied with depth at golf courses across Iowa; and (2) interpret relationships of these properties to current golf course management, previous land use, and inherent soil properties.

\section{Materials and methods}

Our study sites consisted of six golf courses across Iowa, which were selected from approximately 421 golf courses in the state. A stratified random design was used to select courses by alphabetically grouping courses based on their location in eastern, central, and western Iowa and separating them into 18-hole and 9-hole classes. Courses were then selected using a random number generator. If permission for sampling was not obtained from the course, the next randomly selected course was chosen. Ultimately, three 18hole and three 9-hole courses were selected (Fig. 1). Iowa is comprised of several landform regions that are associated with different glacial advances and post-glacial erosion (Prior, 1991), and courses were selected in a variety of landform regions. One course was located on the Iowan surface landform region in eastern Iowa which consists of a significantly dissected glacial landscape and loamy pedisediment. Two courses were located on the southern Iowa drift plain, which is a highly weathered pre-Illinoian glacial landscape capped in loess. Finally, three courses were located on the Des Moines lobe which consists of recent Wisconsinan age glacial deposits and hummocky topography (Table 1).

Three of the courses (Central 9, West 9, and West 18) were combined public and private use in towns of less than 5000 people. The other three courses (East 9, East 18, and Central 18) were privately managed country clubs positioned in communities of 10-60000 people. The smaller 9-hole

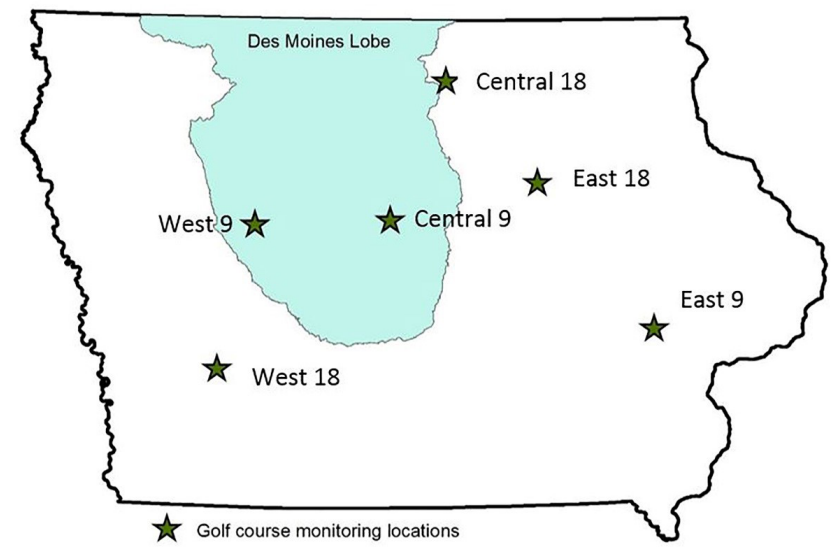

Figure 1. Location map showing the six golf courses chosen for this study.

courses ranged from 20 to 33 ha in size compared to the larger 18-hole courses which ranged from 37 to 68 ha. Tee boxes, greens, and fairways at the courses consisted of bentgrass (Argostis) except at the West 9 and Central 9 courses where fairways consisted of a variety of bentgrass, bluegrass (Poa pratensis), and ryegrass (Lolium perenne). Grass varieties in roughs varied widely but consisted mainly of bentgrass, bluegrass, fescue (Festuca), ryegrass, and annual bluegrass (Роа аппиа) in varying proportions. For each course, superintendents recorded and made available annual fertilizer application rates (typically four applications per year) for tee boxes, fairways, and roughs (Table 2). Generally, the roughs received the least fertilizer while the tee boxes received the most. Four out of six roughs received no fertilizer. Only one course (West 9) applied P fertilizer, whereas all courses applied $\mathrm{N}$ and $\mathrm{K}$ fertilizer. Each course was fertilized between 15 and 30 days prior to soil sampling. Prior land use at the courses was identified from historical aerial photography which was available starting in the 1930s (Natural Resources Geographic Information Systems Library, 2017). Golf course opening dates were verified with the superintendents (Table 1).

At each course, soil samples were collected in conjunction with shallow monitoring well installations being performed for a water quality study (Fig. 2; Schilling and Streeter, 2017). Based on conversation with course superintendents, sampling locations were selected that could be easily accessed multiple times with minimal course disruption. Soil samples were collected according to the stratigraphy encountered at each site. Sampling depths were consistent within each course, but varied among courses based on the depth required to breach the water table for the water quality assessment (Table 1).

Continuous core was collected from each borehole by which the soil was described according to Schoeneberger et al. (2012). Soil samples were collected, air dried and ground to pass a $2 \mathrm{~mm}$ sieve, and lab analyzed according 
Table 1. Golf course site information.

\begin{tabular}{lllllrr}
\hline Course & $\begin{array}{l}\text { Year } \\
\text { opened }\end{array}$ & $\begin{array}{l}\text { Previous } \\
\text { land use }\end{array}$ & Landform & $\begin{array}{l}\text { Parent } \\
\text { material }\end{array}$ & $\begin{array}{r}\text { Max. depth } \\
(\mathrm{cm})\end{array}$ & $\begin{array}{r}\text { Number of } \\
\text { samples }\end{array}$ \\
\hline West 18 & 1963 & Row crop & Southern Iowa drift plain & Loess & 767 & 19 \\
West 9 & 1938 & Row crop & Des Moines lobe & Glacial till & 380 & 20 \\
Central 9 & 1965 & Row crop & Des Moines lobe & Glacial till & 457 & 18 \\
Central 18 & 1915 & No prior history & Des Moines lobe & Glacial till & 506 & 26 \\
East 18 & 1965 & Row crop & Iowan surface & Glacial sediments & 546 & 22 \\
East 9 & 1920 & No prior history & Southern Iowa drift plain & Alluvium & 405 & 22 \\
\hline
\end{tabular}

Table 2. Summary of annual fertilizer rates at selected Iowa golf courses.

\begin{tabular}{|c|c|c|c|c|c|}
\hline Course & Position & $\mathrm{Nkg} \mathrm{ha}^{-1}$ & $\begin{array}{l}\text { Weighted course } \\
\text { average } \mathrm{N} \mathrm{kg} \mathrm{ha}\end{array}$ & $\mathrm{Pkg} \mathrm{ha}^{-1}$ & $\mathrm{Kkg} \mathrm{ha}^{-1}$ \\
\hline West 18 & Tee & 90 & & 0 & 44 \\
\hline West 18 & Rough & 0 & & 0 & 0 \\
\hline West 18 & Fairway & 77 & 28.5 & 0 & 11 \\
\hline West 9 & Tee & 73 & & 5.4 & 22 \\
\hline West 9 & Rough & 0 & & 0 & 0 \\
\hline West 9 & Fairway & 37 & 15.4 & 0 & 6 \\
\hline Central 18 & Tee & 146 & & 0 & 26 \\
\hline Central 18 & Rough & 0 & & 0 & 0 \\
\hline Central 18 & Fairway & 110 & 41.7 & 0 & 0 \\
\hline Central 9 & Tee & 51 & & 0 & 17 \\
\hline Central 9 & Rough & 0 & & 0 & 0 \\
\hline Central 9 & Fairway & 51 & 18.5 & 0 & 17 \\
\hline East 18 & Tee & 87 & & 0 & 132 \\
\hline East 18 & Rough & 112 & & 0 & 17 \\
\hline East 18 & Fairway & 63 & 95.8 & 0 & 107 \\
\hline East 9 & Tee & 169 & & 0 & 20 \\
\hline East 9 & Rough & 22 & & 0 & 7 \\
\hline East 9 & Fairway & 115 & 59.2 & 0 & 19 \\
\hline
\end{tabular}

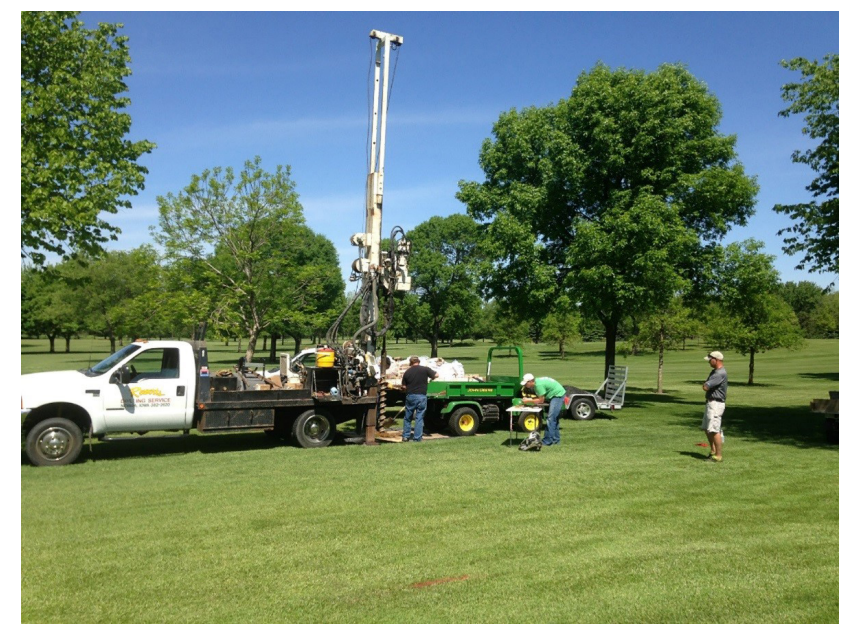

Figure 2. Soil sampling and monitoring well installation at East 18 course. to Brown (1998) for P by strong Bray extraction. Furthermore, total soil carbon (TC) and total soil nitrogen (TN) were determined by elemental analysis via dry combustion and chromatography. Soil organic matter (SOM) was determined by weight loss on ignition (Walkley and Black, 1934) as described by Schulte (1995). Nitrate nitrogen $\left(\mathrm{NO}_{3}\right)$ was measured by segmental flow analysis. Particle size distribution was determined by X-ray absorption. A total of 127 soil samples were collected and analyzed (Table 1).

While specific management strategies at each golf course varied slightly between the tee, rough, and fairway areas, we found through interviews with golf course managers that management strategy varied much more significantly between courses than between locations on the course. For example, the two central courses were located on the same landform region, yet course average $\mathrm{N}$ fertilizer was more than doubled at Central 18 compared to Central 9. When 


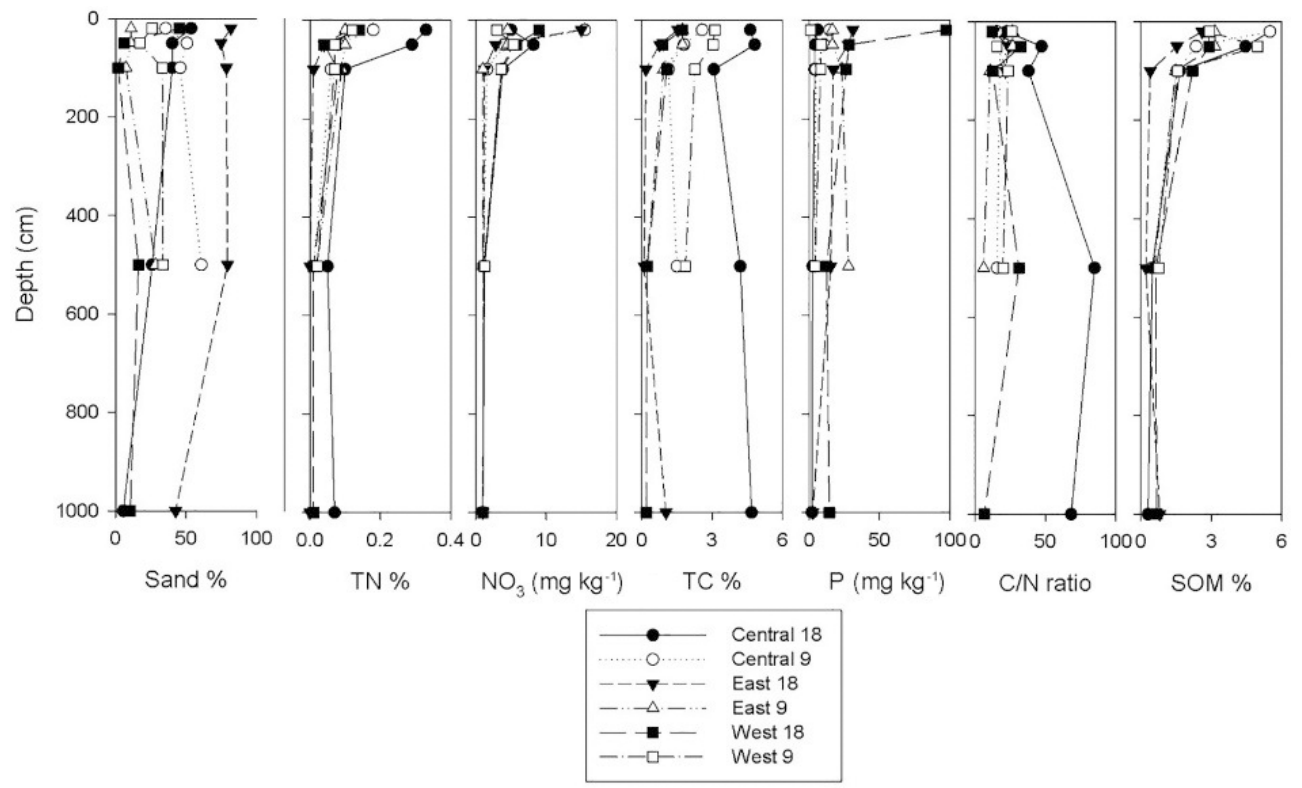

Figure 3. Profile of selected soil constituents with depth at the six Iowa golf courses.

looking at these same two courses, $\mathrm{N}$ fertilization was the same for tees and fairways at the Central 9 course and was only $25 \%$ less on the fairway compared to the tee on the Central 18 course (Table 2). Based on these types of observations, the decision was made to combine samples within golf courses (three sites per course) and compare between courses where differences in management were most pronounced.

\section{Results}

Site stratigraphy was expectedly variable across the range of courses. The courses were located on varying landscape positions and soils formed in a variety of different parent materials including alluvium, glacial till, and loess. Depth of soil development ranged from $26 \mathrm{~cm}$ in glacial till at the central 18 course to $172 \mathrm{~cm}$ in loess at the west 18 course. Soils were less variable within courses, but variations were observed due to golf course management, primarily in terms of soil texture. In many locations, natural sand layers were identified at varying depths as well as evidence of human alteration to soil texture near the soil surface. On average, sand content was $25 \%$ higher in the upper $20 \mathrm{~cm}$ compared to the next lower depth class $(50 \mathrm{~cm}$ depth) for all courses (Table 3 and Fig. 3). Decreasing sand content with depth was most noticeable in courses on the southern Iowa drift plain where average sand content decreased from 45 to $8 \%$. However, since background sand content in soils from different geologic regions ranged widely among the courses (11 to $74 \%$ ), we could not quantify the statistical significance of the sand content differences due to the limited sample size. In essence, testing for changes in sand content in courses could be done within the same landform region because soils have similar background conditions, but in our study we only have one to three courses per landform region.

In contrast to physical properties, varying concentrations of soil chemical properties were identified near the soil surface at multiple courses (Table 3). Course average TC and SOM ranged from 0.45 to 4.11 and 0.76 to $1.89 \%$, respectively and ranged from 0.11 to 4.82 and 0.21 to $5.50 \%$ for individual samples. Likewise, SOM ranged from 2.9 to $5.5 \%$ in samples collected at $20 \mathrm{~cm}$, and was weakly correlated to TC $(r=0.27, p<0.05)$. SOM decreased with depth at all courses $(r=0.47, p<0.05)$ regardless of landform region, whereas TC was not correlated to depth. Additional sampling is required to test the statistical significance of changes in soil chemical properties with depth, but these results do help to highlight the variability in the naturally calcareous parent material. $\mathrm{NO}_{3}$ and $\mathrm{TN}$ concentrations also decreased with increasing depth $(r=0.41$ and $r=0.40$, respectively, $p<0.05) . \mathrm{NO}_{3}$ concentrations were observed to decrease at the greatest rates between the first two depth classes (20 to $50 \mathrm{~cm}$ ), whereas $\mathrm{TN}$ decreased more gradually. $\mathrm{NO}_{3}$ concentrations decreased substantially from 15 to $2 \mathrm{mg} \mathrm{kg}^{-1}$ between 20 and $50 \mathrm{~cm}$ at East 18 located on the Iowan surface while concentrations dropped by more than $50 \%$ at all other locations by $100 \mathrm{~cm}$. C / N ratio ranged from 13 at the East 9 course (floodplain) to 57 at the Central 18 course (glacial upland). $\mathrm{C} / \mathrm{N}$ ratios of more than 20 generally occurred at depths greater than $20 \mathrm{~cm}$. However, C / N ratios were not significantly correlated with depth. Mean $\mathrm{P}$ concentrations ranged from 18 to $67 \mathrm{mg} \mathrm{kg}^{-1}$ and were not correlated with any other soil property measured. 
Table 3. Soil conditions (mean and standard deviation) by depth at Iowa golf courses.

\begin{tabular}{|c|c|c|c|c|c|c|c|c|c|}
\hline Course & $n$ & $\begin{array}{r}\text { Depth class } \\
(\mathrm{cm})\end{array}$ & $\begin{array}{r}\text { Sand } \\
\%\end{array}$ & $\begin{array}{r}\mathrm{P} \\
\mathrm{mg} \mathrm{kg}^{-1}\end{array}$ & $\begin{array}{r}\text { SOM } \\
\%\end{array}$ & $\begin{array}{r}\mathrm{NO}_{3} \\
\mathrm{mg} \mathrm{kg}^{-1}\end{array}$ & $\begin{array}{r}\mathrm{TC} \\
\%\end{array}$ & $\begin{array}{r}\mathrm{TN} \\
\%\end{array}$ & $\mathrm{C} / \mathrm{N}$ \\
\hline Central 18 & 2 & 20 & $53 \pm 42$ & $18 \pm 2$ & $5.50 \pm 4.24$ & $5.00 \pm 2.82$ & $4.63 \pm 0.17$ & $0.33 \pm 0.28$ & $22 \pm 19$ \\
\hline Central 18 & 5 & 50 & $40 \pm 23$ & $18 \pm 9$ & $4.46 \pm 3.69$ & $8.20 \pm 6.22$ & $4.82 \pm 2.35$ & $0.29 \pm 0.21$ & $47 \pm 75$ \\
\hline Central 18 & 6 & 100 & $40 \pm 21$ & $3 \pm 3$ & $1.65 \pm 1.83$ & $3.83 \pm 2.31$ & $3.08 \pm 2.18$ & $0.10 \pm 0.08$ & $30 \pm 33$ \\
\hline Central 18 & 12 & 500 & $26 \pm 25$ & $2 \pm 2$ & $0.48 \pm 0.27$ & $1.25 \pm 0.45$ & $4.21 \pm 2.14$ & $0.05 \pm 0.05$ & $84 \pm 37$ \\
\hline Central 18 & 1 & 1000 & $5 \pm$ & $2 \pm$ & $0.30 \pm$ & $1.00 \pm$ & $4.69 \pm$ & $0.07 \pm$ & $67 \pm$ \\
\hline Central 9 & 2 & 20 & $35 \pm 2$ & $14 \pm 1$ & $5.50 \pm 0.14$ & $15.50 \pm 12.00$ & $2.58 \pm 0.48$ & $0.18 \pm 0.07$ & $14 \pm 4$ \\
\hline Central 9 & 2 & 50 & $50 \pm 1$ & $10 \pm 0$ & $2.35 \pm 1.76$ & $4.00 \pm 4.24$ & $1.81 \pm 0.43$ & $0.08 \pm 0.01$ & $22 \pm 12$ \\
\hline Central 9 & 5 & 100 & $46 \pm 10$ & $4 \pm 9$ & $1.52 \pm 1.13$ & $1.60 \pm 0.89$ & $1.15 \pm 0.84$ & $0.06 \pm 0.05$ & $19 \pm 1$ \\
\hline Central 9 & 9 & 500 & $61 \pm 10$ & $4 \pm 3$ & $0.48 \pm 0.30$ & $1.11 \pm 0.33$ & $1.51 \pm 1.25$ & $0.01 \pm 0.02$ & $15 \pm 5$ \\
\hline East 18 & 1 & 20 & $81 \pm$ & $31 \pm$ & $2.60 \pm$ & $15.00 \pm$ & $1.54 \pm$ & $0.11 \pm$ & $14 \pm$ \\
\hline East 18 & 6 & 50 & $74 \pm 9$ & $27 \pm 1$ & $1.53 \pm 0.95$ & $2.83 \pm 2.31$ & $0.77 \pm 0.54$ & $0.04 \pm 0.03$ & $19 \pm 6$ \\
\hline East 18 & 4 & 100 & $78 \pm 8$ & $17 \pm 1$ & $0.40 \pm 0.21$ & $1.25 \pm 0.50$ & $0.18 \pm 0.12$ & $0.01 \pm 0.00$ & $18 \pm 9$ \\
\hline East 18 & 9 & 500 & $79 \pm 25$ & $15 \pm 3$ & $0.21 \pm 0.16$ & $1.11 \pm 0.33$ & $0.11 \pm 0.08$ & & \\
\hline East 18 & 2 & 1000 & $42 \pm 0$ & $2 \pm 2$ & $0.80 \pm 0$ & $1.00 \pm 0$ & $1.04 \pm 0.10$ & & \\
\hline East 9 & 4 & 20 & $11 \pm 5$ & $16 \pm 1$ & $3.15 \pm 1.96$ & $4.50 \pm 3.31$ & $1.74 \pm 1.77$ & $0.10 \pm 1.12$ & $17 \pm 22$ \\
\hline East 9 & 6 & 50 & $7 \pm 2$ & $23 \pm 5$ & $1.48 \pm 0.42$ & $1.00 \pm 0$ & $0.94 \pm 0.36$ & $0.09 \pm 0.02$ & $10 \pm 2$ \\
\hline East 9 & 12 & 500 & $28 \pm 33$ & $27 \pm 2$ & $0.57 \pm 0.26$ & $1.00 \pm 0$ & $0.22 \pm 0.08$ & $0.02 \pm 0.02$ & $11 \pm 1$ \\
\hline West 18 & 1 & 20 & $45 \pm$ & $97 \pm$ & $2.90 \pm$ & $9.00 \pm$ & $1.72 \pm$ & $0.14 \pm$ & $12 \pm$ \\
\hline West 18 & 6 & 50 & $6 \pm 11$ & $28 \pm 4$ & $2.92 \pm 0.95$ & $5.83 \pm 3.43$ & $0.90 \pm 0.75$ & $0.04 \pm 0.05$ & $22 \pm 22$ \\
\hline West 18 & 3 & 100 & $1 \pm 0$ & $46 \pm 2$ & $2.20 \pm 0.85$ & $3.67 \pm 2.08$ & $1.07 \pm 0.58$ & $0.08 \pm 0.01$ & $13 \pm 5$ \\
\hline West 18 & 6 & 500 & $16 \pm 36$ & $98 \pm 3$ & $0.63 \pm 0.35$ & $1.17 \pm 0.40$ & $0.24 \pm 0.12$ & $0.01 \pm 0.01$ & $31 \pm 36$ \\
\hline West 18 & 3 & 1000 & $10 \pm 6$ & $48 \pm 3$ & $0.67 \pm 0.11$ & $1.00 \pm 0$ & $0.20 \pm 0.05$ & $0.01 \pm 0.01$ & $20 \pm$ \\
\hline West 9 & 1 & 20 & $26 \pm$ & $19 \pm$ & $2.90 \pm$ & $3.00 \pm$ & $3.12 \pm$ & $0.12 \pm$ & $26 \pm$ \\
\hline West 9 & 3 & 50 & $17 \pm 4$ & $28 \pm 9$ & $4.97 \pm 1.54$ & $5.33 \pm 2.08$ & $3.04 \pm 0.84$ & $0.2 \pm 0.07$ & $15 \pm 4$ \\
\hline West 9 & 5 & 100 & $33 \pm 15$ & $21 \pm 2$ & $1.56 \pm 0.92$ & $3.60 \pm 2.61$ & $2.27 \pm 0.84$ & $3.6 \pm 0.05$ & $23 \pm 9$ \\
\hline West 9 & 11 & 500 & $33 \pm 24$ & $38 \pm 4$ & $0.76 \pm 0.56$ & $1.27 \pm 0.64$ & $1.87 \pm 0.86$ & $0.02 \pm 0.03$ & $19 \pm 16$ \\
\hline
\end{tabular}

Table 4. Soil conditions (mean and standard deviation) by course at Iowa golf courses.

\begin{tabular}{lrrrrrrr}
\hline Course & $\begin{array}{r}\text { Sand } \\
\%\end{array}$ & $\begin{array}{r}\mathrm{P} \\
\mathrm{mg} \mathrm{kg}^{-1}\end{array}$ & $\begin{array}{r}\mathrm{SOM} \\
\%\end{array}$ & $\begin{array}{r}\mathrm{NO}_{3} \\
\mathrm{mg} \mathrm{kg}^{-1}\end{array}$ & $\begin{array}{r}\mathrm{TC} \\
\%\end{array}$ & $\begin{array}{r}\mathrm{TN} \\
\%\end{array}$ & $\mathrm{C} / \mathrm{N}$ \\
\hline Central 18 & $33 \pm 25$ & $18 \pm 25$ & $1.89 \pm 2.65$ & $3.46 \pm 3.87$ & $4.11 \pm 2.06$ & $0.13 \pm 0.15$ & $57 \pm 48$ \\
Central 9 & $52 \pm 12$ & $50 \pm 26$ & $1.53 \pm 1.74$ & $3.16 \pm 5.54$ & $1.56 \pm 1.05$ & $0.04 \pm 0.06$ & $18 \pm 6$ \\
East 18 & $74 \pm 19$ & $37 \pm 24$ & $0.76 \pm 0.84$ & $2.22 \pm 3.17$ & $0.45 \pm 0.50$ & $0.01 \pm 0.03$ & $22 \pm 7$ \\
East 9 & $19 \pm 26$ & $57 \pm 22$ & $1.29 \pm 1.26$ & $1.63 \pm 1.86$ & $0.69 \pm 0.91$ & $0.05 \pm 0.06$ & $13 \pm 13$ \\
West 18 & $11 \pm 22$ & $67 \pm 44$ & $1.72 \pm 1.24$ & $3.42 \pm 3.18$ & $0.64 \pm 0.63$ & $0.03 \pm 0.04$ & $23 \pm 22$ \\
West 9 & $30 \pm 20$ & $31 \pm 35$ & $1.7 \pm 1.69$ & $2.55 \pm 2.13$ & $2.20 \pm 0.91$ & $0.06 \pm 0.07$ & $20 \pm 10$ \\
\hline
\end{tabular}

\section{Discussion}

\subsection{Soil physical properties}

In this study, we evaluated soil conditions at six randomly selected Iowa golf courses located in three different landform regions of the state. Despite inherent variation associated with parent materials, study results indicated systematic variation in several soil properties with depth at the Iowa golf course sites that may be directly related to land use. These systematic variations by depth are intriguing, but require fur- ther study to expand sample sizes in order to test statistical significance. Even so, preliminary conclusions may be drawn regarding the significance of land use on soil properties.

At a gross scale, soil particle size distributions were mainly associated with the parent material of the region. Typical sand contents of loess in western Iowa consist of less than $10 \%$ sand, whereas soils formed in glacial till in central Iowa often exceed $50 \%$ sand and may be highly variable (Web Soil Survey, 2016). Our study found less than $10 \%$ sand in the unaltered soil formed in loess from 20 to $100 \mathrm{~cm}$ 
at the West 18 course. However, the surface soil horizon was much higher $(45 \%)$ at this course. Unlike the deeper depth classes, the elevated sand content near the soil surface was not likely an inherent soil property due to the nature of the loess parent material, but rather caused by golf course land use. Our study found sand content was much higher at the four courses located on glacial till derived soils (West 9, Central 9 and 18, and East 18) compared to the courses located on loess (West 18) or alluvium (East 9) (Table 4). With the exception of the Central 9 course, the glacial derived soils exhibited a sharp decrease in sand content between the 20 and $50 \mathrm{~cm}$ depths (as much as $37 \%$ ) that may not be explained primarily by inherent soil properties. Although natural variability in sand content varied widely between landform regions, average sand content for all courses was $25 \%$ higher in the 0 to $20 \mathrm{~cm}$ interval compared to the 20 to $50 \mathrm{~cm}$ depth.

Golf course soils are regularly aerated and top-dressed by adding new sand to the surface of the established soil profile (Bandaranayake et al., 2003; Bauters et al., 2000). Golf course superintendents at our study sites confirmed that topdressing was performed on an annual basis at all but the Central 9 course. This top-dressing management approach explains the elevated sand content near the surface at our study sites. Increased sand content of the surface soil horizons due to top-dressing may have several implications for soil health and development. Altering the particle size distribution of the soil may in turn alter several soil properties including bulk density and porosity (Arya and Paris, 1981; Gupta and Larson, 1979), soil compaction (Bodman and Constantin, 1965), hydraulic conductivity and water holding capacity (Campbell and Shiozawa, 1992; Jabro, 1992), as well as SOM content and distribution (Anderson et al., 1981; Puget et al., 2000; Tiessen and Stewart, 1983), and $\mathrm{NO}_{3}$ concentrations via cation exchange capacity (CEC) (Anderson et al., 1981; Arya and Paris, 1981; Ersahin et al., 2006). Bandaranayake et al. (2003) explained that top-dressing soil with sand prolongs the time required for SOM content to reach equilibrium in the soil profile. Since SOM affects several other soil properties, it is likely that the soil conditions at our study sites are much less stable than those at surrounding non-golf course sites.

Implications of these results may be considered long-term. Soil physical properties, especially soil particle size, develop naturally over geologic timescales and even then, are highly dependent upon the physical properties of the parent material. In the case of our study, we have shown that surficial particle size content has been significantly altered by golf course management over a relatively short time period. While the effects of top-dressing may benefit golf course management in the short-term, these soils have become less stable and their ability to process soil nutrients and water have in effect been permanently altered.

\subsection{Soil chemical properties}

In a similar fashion to the inherent nature of soil texture, TC content may also be primarily dependent on the soil parent material and may be highly spatially variable (Huang et al., 2007). Courses on unaltered glacial deposits (West 9, Central 9, and Central 18) exceeded $4 \%$ TC due to high inorganic carbon concentrations, whereas courses on reworked Iowan surface glacial sediments (East 18) as well as weathered southern Iowa drift plain deposits had TC concentrations less than $2 \%$. These reworked and weathered soils have likely experienced inorganic carbon leaching which has left the soils void of almost all inorganic carbon. This was quite noticeable when comparing TC between landform regions at all depths and it also explains the variability in the $\mathrm{C} / \mathrm{N}$ ratio at depths greater than $100 \mathrm{~cm}$ in our study where the C / N ratio is 4 to 10 times greater in Des Moines lobe soils. The variability in TC (and the $\mathrm{C} / \mathrm{N}$ ratio below $100 \mathrm{~cm}$ ) which we have identified through this study may be entirely affected by parent material and natural weathering patterns and serve to highlight geologic variation across landform regions.

Soil chemical properties including SOM at Iowa golf courses were altered from their long-term equilibrium conditions established under native perennial vegetation in response to modern agricultural management and urban land use. For example, agricultural drainage in conjunction with row crop agriculture can decrease SOM between 24 and $89 \%$ compared to that of perennially managed soils (Knops and Tilman, 2000; Kucharik et al., 2001; VandenBygaart et al., 2003). In urban areas, Qian and Follett (2002) conducted a study on the effects of land use change to turfgrass and found that previous land use imparted a strong baseline control on SOM concentrations. Bandaranayake et al. (2003) estimated that turfgrass systems (e.g., golf courses) could sequester up to $32 \mathrm{Mgha}^{-1}$ of soil organic carbon (approximately $64 \mathrm{Mg} \mathrm{ha}^{-1}$ of SOM) in the top $20 \mathrm{~cm}$ of soil within 30 years of establishment. At the Iowa golf courses, we observed substantially lower SOM contents in samples collected below $20 \mathrm{~cm}$. Concentrations were highest in the uppermost layer and decreased with depth at all courses. Although accumulation of SOM in the upper $20 \mathrm{~cm}$ is consistent with Bandaranayake et al. (2003), attributing specific SOM changes to golf course management is not possible with our study. The SOM profiles could define native perennial, agricultural, or urban turfgrass land use. Still, the implications of SOM alteration must be considered. SOM content may directly impact the soils ability to retain water and improve its quality via filtration (Rawls et al., 2003) in addition to buffering the effects of climate change (Lal, 2004). Further sampling and critical analysis is necessary to draw definitive conclusions about the effects of golf course management on SOM.

In agricultural systems, application of $\mathrm{N}$ fertilizer has been found to migrate through the soil profile (De Haan et al., 2017; Tomer and Burkart, 2003). In the deep loess soils of 
western Iowa, Tomer and Burkart (2003) documented a zone of high soil $\mathrm{NO}_{3}$ located $17 \mathrm{~m}$ below the land surface due to an over-application of commercial fertilizer 20 years earlier. De Haan et al. (2017) observed that cropping systems have a large impact on residual soil $\mathrm{NO}_{3}$ in the upper $1.8 \mathrm{~m}$ of the soil profile. Residual soil $\mathrm{NO}_{3}$ in the soil profile under continuous corn with a ryegrass cover crop was more than seven times higher than a perennial grass system. Others have similarly observed residual $\mathrm{NO}_{3}$ concentrations in soil under agricultural land use in Iowa as high as $60 \mathrm{mg} \mathrm{kg}^{-1}$ (Blackmer et al., 1989). However, the golf courses in our study applied varying rates of slow release $\mathrm{N}$ fertilizer to tee boxes and fairways, and only two courses (East 9 and 18) applied $\mathrm{N}$ fertilizer to the roughs (Table 2). We estimated (based on typical bulk density values for surface soils in Iowa) that soil $\mathrm{NO}_{3}$ concentrations ranged from 15 to $35 \mathrm{~kg} \mathrm{ha}^{-1}$ for our study sites. Our study shows evidence of higher $\mathrm{NO}_{3}$ levels in golf course soils than that of typical perennially managed soils (less than $10 \mathrm{~kg} \mathrm{ha}^{-1}$ ), but not necessarily as high as typical agricultural management $\left(40-70 \mathrm{~kg} \mathrm{ha}^{-1}\right.$ ) (De Haan et al., 2017). Recent studies provide evidence that once application of $\mathrm{N}$ fertilizer ceases, the top $1 \mathrm{~m}$ of the soil may return to native concentrations of $\mathrm{NO}_{3}$ within 10 years (Streeter and Schilling, 2017). Since the courses in our study have been established for over 50 years, it is likely that the current $\mathrm{NO}_{3}$ concentrations near the soil surface reflect golf course management rather than historical agricultural practices. Overall, limited field-scale research suggests that nutrients like $\mathrm{NO}_{3}$ which are discharged from turf managed soils at golf course facilities are typically lower than levels of major concern (King et al., 2007). However, a recent study in Iowa has suggested that a decade-long delay may be expected between changes in golf course management and groundwater quality (Schilling and Streeter, 2018, 2017). Therefore, continued monitoring is necessary to assess changes in soil nutrients via golf course management and their impacts on environmental quality over time.

$\mathrm{P}$ concentrations at the courses were not correlated with any other soil property measured during our study. Furthermore, P fertilizer was only applied at one course (West 9) on the rough. Typically, background $\mathrm{P}$ concentrations in Iowa soils vary from 0 to $100 \mathrm{mg} \mathrm{kg}^{-1}$ depending on the mineralogy of the soil parent material (Fenton, 1999). Loess derived soils generally have the highest $\mathrm{P}$, while glacial till derived soils will have some of the lowest P concentrations (Fenton, 1999). Similarly, our study identified the highest $P$ concentrations at the West 18 course (loess derived soil) and the lowest $\mathrm{P}$ concentrations at the Central 18 course (glacial till derived soil). Our study results suggest no significant alterations to background soil $\mathrm{P}$ concentrations by golf course management.

\section{Conclusions}

In this study, systematic variation in soil properties including sand content, $\mathrm{NO}_{3}$, and $\mathrm{SOM}$ were observed with depth at six Iowa golf courses among three landform regions. Variability in sand content was identified between the 20 and $50 \mathrm{~cm}$ depth classes at all courses, where sand content decreased by as much as $37 \%$. Highest concentrations of SOM and $\mathrm{NO}_{3}$ were found in the shallowest soils, whereas TC and P variability was not related to golf course management and did not correlate with depth. Although many of the soil properties measured for this study may be influenced by parent material and native vegetation, sand content and $\mathrm{NO}_{3}$ were found to be directly related to golf course management, particularly at shallow depths. The effects of golf course management dissipated with depth and deeper soil variations were primarily due to natural geologic conditions. These two soil properties which were most noticeably altered by golf course management may directly impact crop productivity, soil health, and water quality and while $\mathrm{NO}_{3}$ may be altered relatively quickly in soil through natural processes, particle size of the soil may not be altered without extensive mitigation. Iowa golf courses continue to be developed in areas of land use change from historically native prairies and more recently agricultural to urban landscapes. As soils are continually altered by human impacts, it is imperative that we monitor the changes, both physical and chemical, in order to establish management practices that maintain environmental sustainability and productivity. Further work is recommended to increase the sample size of course sites within different landform regions to better quantify the variability of soil properties with depth. Likewise, additional investigation of spatial patterns within individual courses would improve characterization of soil quality patterns among managed and unmanaged areas. Despite the limitations, our study indicates that golf course management is impacting both short-term (soil N) and long-term (physical) quality of surface and subsurface soils.

Data availability. Data are available in the Supplement.

Supplement. The supplement related to this article is available online at: https://doi.org/10.5194/soil-4-93-2018-supplement.

Competing interests. The authors declare that they have no conflict of interest.

Edited by: Carolina Boix-Fayos

Reviewed by: Brice Prudat and Andreas Baumgarten 


\section{References}

Anderson, D., Saggar, S., Bettany, J., and Stewart, J.: Particle size fractions and their use in studies of soil organic matter: I. The nature and distribution of forms of carbon, nitrogen, and sulfur, Soil Sci. Soc. Am. J., 45, 767-772, 1981.

Arya, L. M. and Paris, J. F.: A physicoempirical model to predict the soil moisture characteristic from particle-size distribution and bulk density data, Soil Sci. Soc. Am. J., 45, 1023-1030, 1981.

Balogh, J. C. and Walker, W. J.: Golf course management \& construction: Environmental issues, CRC Press, Boca Raton, FL, USA, 1992.

Bandaranayake, W., Qian, Y., Parton, W., Ojima, D., and Follett, R.: Estimation of soil organic carbon changes in turfgrass systems using the CENTURY model, Agron. J., 95, 558-563, 2003.

Bauters, T., Steenhuis, T., DiCarlo, D., Nieber, J., Dekker, L., Ritsema, C., Parlange, J.-Y., and Haverkamp, R.: Physics of water repellent soils, Journal of Hydrology, 231, 233-243, 2000.

Blackmer, A., Pottker, D., Cerrato, M., and Webb, J.: Correlations between soil nitrate concentrations in late spring and corn yields in Iowa, J. Prod. Agric., 2, 103-109, 1989.

Bodman, G. and Constantin, G.: Influence of particle size distribution in soil compaction, Calif. Agr., 36, 567-591, 1965.

Brown, J. R.: Recommended chemical soil test procedures for the North Central Region, Missouri Agricultural Experiment Station, University of Missouri-Columbia, 1998.

Campbell, G. and Shiozawa, S.: Prediction of hydraulic properties of soils using particle-size distribution and bulk density data, Indirect methods for estimating the hydraulic properties of unsaturated soils, University of California, Riverside, 317-328, 1992.

De Haan, R. L., Schuiteman, M. A., and Vos, R. J.: Residual soil nitrate content and profitability of five cropping systems in northwest Iowa, PloS one, 12, e0171994, https://doi.org/10.1371/journal.pone.0171994, 2017.

Doran, J. W. and Zeiss, M. R.: Soil health and sustainability: managing the biotic component of soil quality, Appl. Soil Ecol., 15, 3-11, 2000.

Ersahin, S., Gunal, H., Kutlu, T., Yetgin, B., and Coban, S.: Estimating specific surface area and cation exchange capacity in soils using fractal dimension of particle-size distribution, Geoderma, 136, 588-597, 2006.

Fenton, T.: Phosphorus in Iowa soils, Agronomy Department, Iowa State University, 1999.

Glanz, J.: Saving our soil: solutions for sustaining earth's vital resource, Johnson Books, 1995.

Gupta, S. and Larson, W.: Estimating soil water retention characteristics from particle size distribution, organic matter percent, and bulk density, Water Resour. Res., 15, 1633-1635, 1979.

Huang, X., Senthilkumar, S., Kravchenko, A., Thelen, K., and Qi, J.: Total carbon mapping in glacial till soils using near-infrared spectroscopy, Landsat imagery and topographical information, Geoderma, 141, 34-42, 2007.

Jabro, J.: Estimation of saturated hydraulic conductivity of soils from particle size distribution and bulk density data, T. ASAE, 35, 557-560, 1992.

King, K., Balogh, J., Hughes, K., and Harmel, R.: Nutrient load generated by storm event runoff from a golf course watershed, J. Environ. Qual., 36, 1021-1030, 2007.
Knops, J. M. and Tilman, D.: Dynamics of soil nitrogen and carbon accumulation for 61 years after agricultural abandonment, Ecology, 81, 88-98, 2000.

Kucharik, C. J., Brye, K. R., Norman, J. M., Foley, J. A., Gower, S. T., and Bundy, L. G.: Measurements and modeling of carbon and nitrogen cycling in agroecosystems of southern Wisconsin: potential for SOC sequestration during the next 50 years, Ecosystems, 4, 237-258, 2001.

Lal, R.: Soil carbon sequestration impacts on global climate change and food security, Science, 304, 1623-1627, 2004.

Natural Resources Geographic Information Systems Library: available at: https://geodata.iowa.gov/, last access: April 2017.

Prior, J. C.: Landforms of Iowa, University of Iowa Press, 1991.

Puget, P., Chenu, C., and Balesdent, J.: Dynamics of soil organic matter associated with particle-size fractions of water-stable aggregates, Eur. J. Soil Sci., 51, 595-605, 2000.

Qian, Y. and Follett, R. F.: Assessing soil carbon sequestration in turfgrass systems using long-term soil testing data, Agron. J., 94, 930-935, 2002.

Rawls, W., Pachepsky, Y. A., Ritchie, J., Sobecki, T., and Bloodworth, H.: Effect of soil organic carbon on soil water retention, Geoderma, 116, 61-76, 2003.

Schilling, K. E. and Streeter, M. T.: Groundwater Nutrient Concentrations and Mass Loading Rates at Iowa Golf Courses, J. Am. Water Resour. As., 54, 211-224, https://doi.org/10.1111/17521688.12604, 2017.

Schilling, K. E. and Streeter, M. T.: Groundwater Nutrient Concentrations and Mass Loading Rates at Iowa Golf Courses, J. Am. Water Resour. As., 54, 211-224, 2018.

Schoeneberger, P. J., Wysocki, D. A., Benham, E. C., and Soil Survey Staff: Field Book for Describing and Sampling Soils, Version 3.0, Government Printing Office, Washington, D.C., 2012.

Schulte, E.: Recommended soil organic matter tests, Recommended Soil Testing Procedures for the North Eastern USA, Northeastern Regional Publication, 52-60, 1995.

Streeter, M. T. and Schilling, K. E.: Soil Properties in Native, Reconstructed, and Farmed Prairie Potholes: A Chronosequence Study of Restoration Timeframes, Ecological Restoration, 35, 6$12,2017$.

Tiessen, H. and Stewart, J.: Particle-size fractions and their use in studies of soil organic matter: II. Cultivation effects on organic matter composition in size fractions, Soil Sci. Soc. Am. J., 47, 509-514, 1983.

Tomer, M. and Burkart, M.: Long-term effects of nitrogen fertilizer use on ground water nitrate in two small watersheds, J. Environ. Qual., 32, 2158-2171, 2003.

VandenBygaart, A., Gregorich, E., and Angers, D.: Influence of agricultural management on soil organic carbon: A compendium and assessment of Canadian studies, Can. J. Soil Sci., 83, 363380, 2003.

Walkley, A. and Black, I. A.: An examination of the Degtjareff method for determining soil organic matter, and a proposed modification of the chromic acid titration method, Soil Sci., 37, 29$38,1934$.

Web Soil Survey: available at: http://websoilsurvey.nrcs.usda.gov, last access: December 2016. 